\title{
Relationship of Personal Hygiene and Nutritional Status to Intestinal Parasitic Infection in Simo, Boyolali
}

\author{
Sherlina Rintik Tirta Ayu*, Sri Haryati, Yulia Sari, and Sutartinah Handayani \\ Parasitology and Mycology Department, Faculty of Medicine, Universitas Sebelas Maret, Jl. Ir. Sutami 36A \\ Kentingan Jebres Surakarta 57126, Indonesia \\ *Corresponding author: sherlinarintiktirtaayu@student.uns.ac.id
}

\begin{abstract}
Intestinal parasitic infections are caused by protozoa, STH and non-STH worms. Immunity, which can be determined by measuring nutritional status, and personal hygiene can affect the occurrence of intestinal parasite infections. This study aims to determine the relationship between personal hygiene and nutritional status against intestinal parasite infections in elementary school students in Simo Boyolali. This type of analytic observational research with a cross sectional approach. Total sampling was taken at elementary school of Wates, Talakbroto 1, and Kedunglengkong 1 Simo, Boyolali. There were 11 students with worms infections, 16 with protozoa infections, and 4 with worms and protozoa infection. There was a relationship between washing hands before eating $(\mathrm{p}=0.004)$, after eating (0.027), after defecating $(\mathrm{p}=0.04)$, biting nails $(\mathrm{p}=0.008)$, wearing footwear when leaving the house $(\mathrm{p}=0.008)$, removing shoes while playing during school breaks $(\mathrm{p}=0.001)$, and nutritional status $(\mathrm{p}=$ $0.002)$ with intestinal parasite infection. There was no relationship between nail clipping once a week $(\mathrm{p}=0.118)$ and the availability of a latrine $(\mathrm{p}=0.416)$ with intestinal parasitic infections. So, there is a relationship between personal hygiene (washing hands before eating, after eating, after defecating, biting nails, wearing footwear when leaving the house, removing shoes when playing during school breaks, and nutritional status) and intestinal parasitic infections.
\end{abstract}

Keywords: elementary school; protozoa; worms

Cite this as: Ayu, S. R. T., Hartati, S., Sari, Y., and Handayani, S. (2021). Relationship of Personal Hygiene and Nutritional Status to Intestinal Parasitic Infection in Simo, Boyolali. Journal of Biodiversity and Biotechnology. 1(1), 38-45. doi: http://dx.doi.org/10.20961/jbb.v1i1.50237.

\section{Introduction}

Intestinal parasitic infections mostly occur in areas with tropical and subtropical climates, especially in developing countries (1). Indonesia is one of the endemic countries for intestinal parasitic infections, mainly caused by protozoa (most commonly Entamoeba histolytica, Giardia lamblia, and Blastocystis hominis), worms that are classified as Soil Transmitted Helminths (STH) (Ascaris lumbricoides, Trichuris trichiura, Necator americanus, Ancylostoma duodenale and Strongyloodenale. stercoralis) and non-STH worms, namely Enterobius vermicularis and Taenia $s p$. (2,3). One of the factors that influence the occurrence of intestinal parasitic infection is the individual factor consisting of immunity and personal hygiene. Immunity is influenced by the intake of nutrients that enter the body where the intake of these nutrients can be determined by measuring nutritional status. Decreased nutritional status indicates decreased immunity so that the body is susceptible to intestinal parasitic infections. Personal hygiene includes washing hands, nail hygiene, defecating, and wearing footwear. Intestinal parasite transmission through faecal oral and intestinal parasite contamination in food and water, so that personal hygiene is the most priority in preventing the occurrence of this intestinal parasitic infection $(4,5,6,7)$.

As much as one third of the world's population has intestinal parasitic infections (2). The highest prevalence is in 270 million preschool children and 600 million school-age children (7). This infection in children occurs because the child does not maintain personal hygiene and is less aware of clean and healthy 
living, and in children who have poor nutritional status can also affect the occurrence of this intestinal parasitic infection $(1,4)$. The prevalence of intestinal parasitic infection in Boyolali, Central Java, cannot be found equally, but it has been found in several locations in Boyolali, where 35 children (47.3\%) had STH infection in Teras District, Boyolali Regency (8). In addition, to determine the possibility of intestinal parasitic infection, it can be seen from the proportion of risk factors for intestinal parasitic infection, namely personal hygiene, including washing hands properly $(56.75 \%)$ and defecating behavior $(89.42 \%)$ at ages 5-9. years and $89.36 \%$ at the age of 10-14 years can indicate that the behavior of washing hands and defecating is not correct, so that intestinal parasitic infections can occur $(9,10)$. Geographically, the soil structure of Boyolali Regency, especially in the northeast area around the sub-district Karanggede and Simo consist of clay / clay so that the possibility of intestinal parasitic infection can still occur. The nutritional status of children aged 5-12 years in Boyolali Regency is $31.43 \%$, not included in the normal group where the nutritional status is not normal can cause the body to be susceptible to intestinal parasitic infections so that it can strengthen the possibility of developing intestinal parasitic infections (9). The purpose of this study was to determine the relationship of personal hygiene to intestinal parasitic infection of elementary school students in Simo, Boyolali and to determine the relationship of nutritional status to intestinal parasitic infection of elementary school students in Simo, Boyolali.

\section{Material and Methods}

This type of research is analytic observational with a cross sectional approach. This research was conducted in 2 stages, namely data collection was carried out at elementary school of Wates, Talakbroto 1, and Kedunglengkong 1 which are located in Simo District, Boyolali Regency, Central Java from February to August 2020 by providing a sheet of willingness to be the subject of research to student guardians and Guardians who agree were given a personal hygiene questionnaire to fill out, then the BMI of the students were measured and stool samples taken. The second stage was sample examination which was carried out at the Parasitology Laboratory of the Faculty of Medicine, Sebelas Maret University,
Surakarta City, Central Java from February to August 2020 using the Kato Katz method and Trikrom staining.

The population of this study were 68 students of Wates elementary school, 53 of Talakbroto 1 elementary school, and 74 of Kedunglengkong 1 elementary school, so that the total population of the three elementary schools was 195 people. The sample of this study used a non-probability sample, namely total sampling technique or saturated sampling technique, in which all members of the population become the research sample (11). The data obtained from this study were analyzed statistically using SPSS, by performing univariate analysis, bivariate analysis using chi-square test, and multivariate analysis using logistic regression test.

\section{Results and Discussion \\ Description of research location}

Simo District is one of the sub-districts in Boyolali Regency and is located in the middle of the western part and directly adjacent to Semarang Regency. The area of Simo District is $4,804,0275 \mathrm{Ha}$ (more than $44 \%$ of rice fields) and a population density of 1,026 people per $\mathrm{km}^{2}$. Simo sub-district consists of 13 villages, namely Pelem, Bendungan, Temon, Teter, Simo, Walen, Pentur, Gunung, Talakbroto, Kedunglengkong, Blagung, Sumber, and Wates (12). This research was conducted in 3 villages, namely Talakbroto village at Talakbroto 1 elementary school, Kedunglengkong village at Kedunglengkong 1 elementary school, and Wates village at Wates elementary school. Simo sub-district is located at an altitude of 150,325 $\mathrm{m}$ above sea level with a moderate climate, which is around $27^{\circ} \mathrm{C}$. The rainfall in Simo District reaches $1,938 \mathrm{~mm}$. Soil structure in Simo sub-district is clay soil with the association soil of dark gray grumosol and dark brown mediterranean soil (13).

\section{Subject characteristics}

The age characteristics of the respondents in table 1 showed that the average age of the respondents was 9.7 years, with the youngest age being 6 years old as many as 4 students and the oldest age being 13 years as many as 2 students. Age 11 years was the age of the most respondents in this study, as many as 30 students. The gender characteristics of the respondents in table 2 indicate that there were 
more female respondents than male respondents.

Table 1. Subject characteristics by age

\begin{tabular}{ccccc}
\hline Mean & Mod & SD & Min & Max \\
\hline 9.7 & 11 & 1.652 & 6 & 13 \\
\hline
\end{tabular}

Table 2. Subject characteristics by gender

\begin{tabular}{lcc}
\hline \multicolumn{1}{c}{ Gender } & Frequency $(\mathrm{n})$ & $(\%)$ \\
\hline Male & 59 & 44.7 \\
Female & 73 & 55.3 \\
Total & 140 & 100 \\
\hline
\end{tabular}

Intestinal parasitic infection

Table 3. Frequency distribution of intestinal parasitic infection

\begin{tabular}{|c|c|c|}
\hline $\begin{array}{l}\text { Intestinal } \\
\text { Parasitic } \\
\text { Infection }\end{array}$ & $\begin{array}{c}\text { Frequency } \\
\text { (people) }\end{array}$ & $(\%)$ \\
\hline $\begin{array}{l}\text { Positive } \\
\text { Worms }\end{array}$ & 31 & 23.5 \\
\hline $\begin{array}{l}\text { A. } \\
\text { lumbricoides }\end{array}$ & 4 & 3 \\
\hline $\begin{array}{l}\text { Hookworm } \\
\text { T. trichiura } \\
\text { A. }\end{array}$ & $\begin{array}{l}1 \\
5 \\
1\end{array}$ & $\begin{array}{l}0.8 \\
3.8 \\
0.8\end{array}$ \\
\hline $\begin{array}{l}\text { lumbricoides } \\
\text { and T. trichiura } \\
\text { Protozoa }\end{array}$ & & \\
\hline B. hominis & 13 & 9.8 \\
\hline E. coli & 1 & 0.8 \\
\hline E. histolytica & 1 & 0.8 \\
\hline $\begin{array}{l}\text { B. hominis } \\
\text { and E. coli } \\
\text { Worms dan } \\
\text { Protozoa }\end{array}$ & 1 & 0.8 \\
\hline $\begin{array}{l}\text { B. hominis } \\
\text { and } A \text {. } \\
\text { lumbricoides }\end{array}$ & 4 & 3 \\
\hline Negative & 101 & 76.5 \\
\hline Total & 132 & 100 \\
\hline
\end{tabular}

Table 3 above showeds that there were 31 respondents experiencing intestinal parasitic infections, so no more than $50 \%$ of the total respondents experienced intestinal parasitic infections. Of the 31 respondents, there were 15 people who only experienced infection of one protozoan species, this shows that protozoa infection was the most common infection in this study. Respondents were 1 person infected with two species of protozoa, namely Blastocystis hominis and Entamoeba coli. There were 10 respondents who were infected with one species of worm. Respondents with infection of two species of worms namely Ascaris lumbricoides and Trichuris trichiura were 1 person. Respondents with concurrent worm and protozoa infections, namely Blastocystis hominis and Ascaris lumbricoides infection were 4 people. Blastocystis hominis infection occurs most frequently in this study because Blastocystis hominis infection occurs because there is an association with poor personal hygiene, exposure to animals, consumption of air or food contaminated with this parasite, and in immunocompromised people (14). The age of children can also be one of the reasons for this infection because the age of children with personal hygiene and toilet training is still low and children with low nutritional status can cause low body immunity so that the body is susceptible to infection with these parasites. STH worm infections including Ascaris lumbricoides, Trichuris trichiura, and Hookworm are only a few infected, this can be due to personal hygiene, especially the use of good footwear so that there are fewer infections.

Analysis of the relationship between the habit of washing hands and parasitic intestinal infection

The relationship between the habit of washing hands before eating, after eating, and after defecating with intestinal parasitic infections in this study showed a relationship between the two, this is in line with other studies which state that there is a relationship between the habit of washing hands and the incidence of asymptomatic giardiasis (15). Another study also states that there is a relationship between the habit of washing hands before eating and after defecating with the incidence of worms (16). The results of this study also showed that students who had done the habit of washing their hands before eating, after eating, and after defecating were still infected with intestinal parasites due to improper or incorrect hand washing, personal hygiene apart from bad hand washing, not washing hands before eating snacks, food hygiene, food processing, and poor food equipment, unavailability of hand washing facilities or inadequate facilities such as unavailability of soap or clean running water, lack of knowledge about the importance of washing hands in preventing disease transmission, and other parties such as health workers, families, and teachers who are lacking in doing basic health promotion such as hand 
washing habits $(16,17)$. Students who do not have the habit of washing their hands both before and after eating and after defecating but not infected with intestinal parasites can occur because personal hygiene besides washing hands is good and is supported by a good environment.

Table 4. Analysis of the relationship between the habit of washing hands and parasitic intestinal infection

\begin{tabular}{ccccc}
\hline \multicolumn{5}{c}{ Intestinal Parasitic Infection } \\
\hline before & Yes & Positive & Negative & P-value \\
eating & No & 7 & 97 & \multirow{2}{*}{$0 / 004$} \\
\hline after & Yes & 27 & 4 & \\
eating & No & 4 & 2 & $0 / 027$ \\
\hline after & Yes & 28 & 100 & \multirow{2}{*}{0.04} \\
defecating & No & 3 & 1 & \\
\hline Note: *Fisher test
\end{tabular}

Analysis of the relationship between nail hygiene and Intestinal parasitic infection

The results of this study indicate that there was no relationship between the habit of cutting nails once a week with intestinal parasitic infections, but there was an association between nail biting habits and intestinal parasitic infections. Another study which is in line with the study stated that there was no association between nail hygiene and STH infection (18). The absence of this relationship was due to the many factors, both personal hygiene and the student's environment that affect intestinal parasitic infections. Although though one did not cut their nails once a week, one still conducted other personal hygiene procedure such as washing hands to prevent the occurrence of intestinal parasitic infections. Different nail growth between individuals can cause differences in the frequency of cutting nails in that individual. As many as 9 students in this study were not infected even though they did not have the habit of cutting nails once a week where the number was more than students who were negative for intestinal parasitic infections even though they had practiced the habit of cutting nails once a week. This could also indicate that there was no relationship between the these two variables. Students who did not bite their nails but are still infected can be caused by other poor personal hygiene, as well as in children whom were not infected, although nail biting can be caused by other factors that cause intestinal parasitic infection.
Table 5. Analysis of the relationship between nail hygiene and intestinal parasitic infection

\begin{tabular}{|c|c|c|c|c|}
\hline \multicolumn{5}{|c|}{ Intestinal Parasitic Infection } \\
\hline & & Positive & Negative & P-value \\
\hline \multirow{2}{*}{$\begin{array}{l}\text { The habit of } \\
\text { cutting nails } \\
\text { once a week }\end{array}$} & Yes & 25 & 92 & \multirow{2}{*}{0.118} \\
\hline & No & 6 & 9 & \\
\hline Nail biting & Yes & 8 & 7 & \multirow{2}{*}{0.008} \\
\hline habit & No & 23 & 94 & \\
\hline
\end{tabular}

Note: *Fisher test

Analysis of the relationship between Footwear and intestinal parasitic infections

Table 6. Analysis of the Relationship between Footwear and Intestinal Parasitic Infection

\begin{tabular}{lcccc}
\hline \multicolumn{5}{c}{ Intestinal Parasitic Infection } \\
\hline & & Positive & Negative & P-value \\
\hline $\begin{array}{l}\text { The habit of } \\
\text { wearing } \\
\text { footwear }\end{array}$ & Yes & 23 & 94 & \\
$\begin{array}{l}\text { when } \\
\text { leaving the } \\
\text { house* }\end{array}$ & No & 8 & 7 & 0.008 \\
\hline $\begin{array}{l}\text { Habit of } \\
\text { Taking Off }\end{array}$ & Yes & 18 & 26 & \\
$\begin{array}{l}\text { Shoes While } \\
\text { Playing }\end{array}$ & No & 13 & 75 & 0.001 \\
$\begin{array}{l}\text { School } \\
\text { Break** }\end{array}$ & & & & \\
\hline
\end{tabular}

Note: *Fisher test; ${ }^{*}$ Chi-Square test

The results of this study indicated that there was a relationship between the habit of wearing footwear when leaving the house and the habit of removing shoes when playing at school breaks with intestinal parasitic infections. This is in accordance with other studies which stated that there is a relationship between the habit of wearing footwear and worm infections (17); as well as other studies which stated that not using good footwear has 14 times greater risk of experiencing worm infections than using good footwear (19). Students whom were not infected even though they did not use footwear can occur because they practice good personal hygiene procedures. Whereas children whom were infected even though they already have the habit of wearing footwear can be caused by other factors that cause intestinal parasitic infection.

Analysis of the relationship between latrine availability at home and parasitic intestinal infection

The results of this study indicated that there was no relationship between the 
availability of latrines at home with intestinal parasitic infections. This is in line with other studies which stated that there is no relationship between the availability of latrines for intestinal parasite infections (20). The absence of this relationship might be due to the various factors regarding latrine availability described above which were not examined in this study. Students who already have a latrine but were still infected with intestinal parasites can be caused by the latrine that was not in accordance with healthy latrine standards. Requirements for a healthy latrine are as follows: not polluting water sources (minimum distance from water sources 10-15 meters), odorless, not polluting the surrounding environment, water and soap available, cleaning tools available, watertight floors and adequate space, adequate lighting and ventilation, available, protective walls and roofs, untouched dirt, easy to clean and safe (21).

Table 7. Analysis of the relationship between latrine availability at home and parasitic intestinal infection

\begin{tabular}{|c|c|c|c|c|}
\hline \multicolumn{5}{|c|}{ Intestinal Parasitic Infection } \\
\hline & & Positive & Negative & P-value \\
\hline $\begin{array}{l}\text { Latrines } \\
\text { at home }\end{array}$ & $\begin{array}{l}\text { Yes } \\
\text { No }\end{array}$ & $\begin{array}{c}30 \\
1\end{array}$ & $\begin{array}{c}100 \\
1\end{array}$ & 0.416 \\
\hline
\end{tabular}

Note: *Fisher test

Analysis of the relationship between nutritional status and parasitic intestinal infection

Table 8. Analysis of the Relationship Between Nutritional Status and Parasitic Intestinal Infection

\begin{tabular}{|c|c|c|c|c|}
\hline \multicolumn{5}{|c|}{ Intestinal Parasitic Infection } \\
\hline & & Positive & Negative & $P$ P-value \\
\hline \multirow{2}{*}{$\begin{array}{l}\text { Nutritional } \\
\text { status }\end{array}$} & Normal & 20 & 91 & 0.00 \\
\hline & $\begin{array}{l}\text { Below } \\
\text { Normal }\end{array}$ & 11 & 10 & 2 \\
\hline
\end{tabular}

Note: *Fisher test

Nutritional status in this study became an independent variable against intestinal parasitic infection, so that nutritional status was one of the causes of intestinal parasitic infection. The results of this study indicated that there was a relationship between nutritional status and intestinal parasitic infection. This indicated that a BMI below normal, which is below the SD-2 line affected the occurrence of intestinal parasitic infections, which means that poor nutritional status can decrease immunity in response to parasitic infections. Another study stated that poor nutritional status will lead to a weak immune system so that the body will be susceptible to infection, one of which is intestinal parasitic infection (22). Students who have normal nutrition but were infected with intestinal parasites can occur due to various factors that affect intestinal parasitic infections, one of which is personal hygiene. Hence, if personal hygiene is not good but the nutritional status is good, intestinal parasitic infections can occur.

Personal hygiene, nutritional status, and intestinal parasitic infection

Table 9. Hosmer and Lemeshow Test

\begin{tabular}{ccc}
\hline $\begin{array}{c}\text { Chi- } \\
\text { square }\end{array}$ & df & P-value \\
\hline 2,929 & 5 & 0.711 \\
\hline
\end{tabular}

Note: *Regression Logistic test

Table 9 shows that the p-value was 0.711 , where the value was greater than the significance level of 0.05 so that the logistic model was appropriate, this means that this logistic model can predict the occurrence of intestinal parasitic infections based on personal hygiene and nutritional status.

Table 10. Omnibus Test of Model Coefficients

\begin{tabular}{llll}
\hline & $\begin{array}{l}\text { Chi- } \\
\text { square }\end{array}$ & Df & P-value \\
\hline $\begin{array}{l}\text { Step 1 } \\
\text { Step }\end{array}$ & 45,801 & 9 & 0.000 \\
Block & 45,801 & 9 & 0.000 \\
Model & 45,801 & 9 & 0.000 \\
\hline \multicolumn{4}{l}{ Note: *Regression Logistic test }
\end{tabular}

Table 10 above shows that the p-value was 0.000 , which was less than the significance value of 0.005 , so it was found that there was at least one independent variable in this study, namely each question points on personal hygiene and nutritional status of respondents, that affect the dependent variable of this study, namely intestinal parasitic infection.

Table 11. Model summary

\begin{tabular}{ccc}
\hline-2 Log & Cox \& Snell & Nagelkerke $R$ \\
likelihood & $R$ Square & Square \\
\hline 98.097 & 0.293 & 0.442 \\
\hline Note: *Regression Logistic test
\end{tabular}

Table 11 showed the Nagelkerke $R$ Square value of 0.442 , this means that the independent variables in this study were able to 
explain $44.2 \%$ of the dependent variable and the remaining $55.8 \%$ were explained by other variables outside of this study.

Table 12. Variable in the Equation

\begin{tabular}{lc}
\hline \multicolumn{1}{c}{ Variable } & $\operatorname{Exp}(\mathrm{B})$ \\
\hline $\begin{array}{l}\text { The habit of washing hands before } \\
\text { eating }\end{array}$ & 8.675 \\
$\begin{array}{l}\text { The habit of washing hands after } \\
\text { eating }\end{array}$ & 2.077 \\
$\begin{array}{l}\text { The habit of washing hands after } \\
\text { defecating }\end{array}$ & 5.119 \\
$\begin{array}{l}\text { The habit of cutting nails once a } \\
\text { week }\end{array}$ & 3.385 \\
$\begin{array}{l}\text { Nail biting habit } \\
\text { The habit of wearing footwear }\end{array}$ & 0.275 \\
$\begin{array}{l}\text { when leaving the house } \\
\text { The habit of removing shoes when } \\
\text { playing during school breaks }\end{array}$ & 0.508 \\
$\begin{array}{l}\text { Availability of latrines at home } \\
\text { Nutritional status }\end{array}$ & 0.170 \\
\hline
\end{tabular}

Note: *Regression Logistic test

Table 12 showed the value of $\exp (\mathrm{B})$, which is the odd ratio value, so that the following interpretation is obtained.

a. People with the habit of not washing their hands before eating are at 8675 times the risk of developing intestinal parasitic infections.

b. People who do not wash their hands after eating have a 2077 times risk of developing intestinal parasitic infections.

c. People with a habit of not washing their hands after having a bowel movement have a 5119 risks of experiencing intestinal parasitic infections.

d. People who do not cut their nails once a week are at 3385 times the risk of developing intestinal parasitic infections.

e. People with a habit of biting their nails are 0.275 times more likely to develop intestinal parasitic infections.

f. People with the habit of not wearing footwear when leaving the house are 6.508 times more likely to experience intestinal parasitic infections.

g. People with the habit of removing their shoes while playing during school breaks are 0.17 times more likely to develop intestinal parasitic infections.

h. Unavailability of toilets at home has 0.002 times the risk of developing intestinal parasitic infections. i. People with below normal nutritional status have 0.138 times the risk of experiencing intestinal parasitic infections.

Multivariate analysis in this study showed that the logistic model of this study can predict the occurrence of intestinal parasitic infections according to personal hygiene and nutritional status. There was a relationship between the habit of washing hands before eating, after eating, after defecating, the habit of biting nails, the habit of using footwear when leaving the house, the habit of removing shoes while playing during school breaks, and nutritional status with intestinal parasitic infections. In addition, it was also found that $44.2 \%$ of the independent variables in this study were able to explain the dependent variable, namely intestinal parasitic infection. The value of each odd ratio of personal hygiene and nutritional status with intestinal parasitic infection can assess the risk of each independent variable on the dependent variable. The indicated odds ratio showed that latrine unavailability had the greatest risk of experiencing intestinal parasitic infection compared to other independent variables. Although there was no relationship between the two but it can be seen from the discussion that the absence of a latrine can cause intestinal parasitic infection due to the transmission of intestinal parasites through human feces more often occurs.

\section{Conclusion}

This study showed that there was a relationship between personal hygiene which includes the habit of washing hands before eating, after eating, after defecating, biting nails, wearing footwear when leaving the house, and removing shoes when playing during school breaks with intestinal parasitic infections. Other personal hygiene practices, namely cutting the nails once a week and the availability of latrines were not associated with intestinal parasitic infections. Nutritional status was associated with intestinal parasitic infections.

Suggestions for future research are to conduct further research related to factors outside of this study that affect intestinal parasitic infections and to use research instruments as accurate and detailed as possible.

Suggestions for the public are to be able to provide knowledge and awareness about the importance of personal hygiene and nutrition to 
determine nutritional status as a defense for the body's immunity in preventing intestinal parasitic infections.

Suggestions for health service agencies are to routinely check intestinal parasitic infections to prevent transmission of intestinal parasitic infections. Meanwhile, the government should always improve adequate health facilities to minimize the transmission of intestinal parasitic infections.

\section{Acknowledgments}

Researchers would like to thank various parties who have provided support and assistance, namely Dra. Sri Haryati, M.Kes as Head of the Parasitology Laboratory of the Faculty of Medicine, Sebelas Maret University, Sumadi, S.Pd., M.Pd as the Principal of Talakbroto 1 elementary school, Hery Wardaya as Principal of Kedunglengkong 1 elementary school, and Sumardi, S. Pd as Principal of Wates elementary school.

\section{Conflict of Interest}

The limitation of this study is that this study does not perform quantitative fecal microscopic examination so that it cannot determine the severity of infection in respondents, variables outside this study can affect the results of the study because these variables are not tested and are not controlled, and the personal hygiene questionnaire is filled in. by the parents of the students so that there may be bias or not really in accordance with the condition of the respondent.

\section{References}

1. Rosyidah, H. N. and Prasetyo, H. Prevalence of intestinal helminthiasis in children at North Keputran Surabaya at 2017. Journal of Vocational Health Studies, 2018;01:117-120.

2. Amer, O. H., Ashankyty, I. M., and Haouas, N. A. S.. Prevalance of intestinal parasite infections among patients in local public hospitals of hail, Northwestern Saudi Arabia. Asian Pacific Journal of Tropical Medicine. Elsevier (Singapore) Pte Ltd, 2015;1-5. doi: 10.1016/j.apjtm.2015.12.009.

3. Lee, J. and Ryu, J. Current Status of Parasite infections in Indonesia: A literature Review. Korean J Parasitol, 2019;57(4), pp. 329-339.
4. Fransisca, R. O., Iriani, A. D., Mutiksa, F. A., Izati, S., dan Utami, R. K.. Hubungan infeksi parasit usus dengan pengetahuan perilaku hidup bersih sehat pada anak SD Bekasi, 2012; 2-6.

5. Sungkar, S., Pohan, A. P. N., Ramadani, A., Albar, N., Azizah., Nugraha, A. R. A., and Wiria, A. E.. Heavy burden of intestinal parasite infections in Kalena Rongo village, a rural area in South West Sumba, eastern part of Indonesia : a cross sectional study. BMC Public Health. BMC Public Health, 2015; 1-6. doi: 10.1186/s12889-015-2619-z.

6. Saki, J., Khademvatan, S., Rad, M. F., and Gharibzadeh, M.. Prevalence of intestinal parasitic infections in Haftkel County, Southwest of Iran. Int J Infect, 2017;4(4):0-5.

7. Sitotaw, B., Mekuriaw, H., and Damtie, D. Prevalence of intestinal parasitic infections and associated risk factors among Jawi primary school children, Jawi town, north. BMC Infectious Diseases, 2019; 1-10.

8. Nadhiasari, A., Sakiman, B. S., dan Dirgahayu, P.. Hubungan antara infeksi Soil Transmitted Helminths (STH) dengan kadar eosinofil darah tepi pada siswa SD Barengan di Kecamatan Teras, Boyolali [Skripsi] Universitas Sebelas Maret : Digilib UNS; 2014.

9. Dinas Kesehatan Kabupaten Boyolali. Profil kesehatan Kabupaten Boyolali tahun 2018. Boyolali: Dinas Kesehatan Boyolali; 2018.

10. Riskesdas. Laporan provinsi Jawa Tengah riskesdas 2018. Jakarta; 2018b

11. Masturoh, I. dan Anggita T, N. Metodologi penelitian kesehatan. Jakarta: Kementerian Kesehatan RI; 2018.

12. BPS Kabupaten Boyolali, Kecamatan Simo dalam Angka 2019. Boyolali: Badan Pusat Statistik Kabupaten Boyolali, 2019b.

13. BPS Kabupaten Boyolali, Kabupaten Boyolali dalam Angka 2019. Boyolali: Badan Pusat Statistik Kabupaten Boyolali, 2019a.

14. Pramestuti, Nova dan Dewi Saroh. Blastocystis hominis: protozoa usus potensial penyebab diare. SEL Jurnal Penelitian Kesehatan, 2017;4(1):1-12. 
15. Artika, Mentari, Nurhayati, dan Yustini Alioes. Hubungan kebiasaan mencuci tangan dan memotong kuku dengan kejadian giardiasis asimtomatik. Jurnal Kesehatan Andalas, 2017;6(1):70-75.

16. Erna, Aida dan Mukono J. Hubungan karakteristik santri dan kebiasaan mencuci tangan dengan kejadian kecacingan di Pondok Pesantren Kabupaten Blitar. Jurnal Kesehatan Lingkungan, 2015;8(1):14-24.

17. Waqiah, U. Hubungan hygiene perorangan dengan kejadian infeksi kecacingan pada Pemulung Anak Usia Sekolah Dasar di TPA Antang Makassar [Skripsi] Makassar: Universitas Islam Negeri Alauddin, 2010.

18. Dewi, Ratna, N L G D dan Laksmi, D A A S. Hubungan perilaku higienitas diri dan sanitasi sekolah dengan infeksi soil transmitted helminths pada siswa kelas III-VI Sekolah Dasar Negeri No. 5 Delod Peken Tabanan Tahun 2014. E-Jurnal Medika, 2017;6(5):1-4.

19. Pradinata, Bayu, K T, Sudarmaja, I M dan Ariwati, N L. Perilaku siswa SDN 4 antiga kelod karangasem terhdap infeksi soil transmitted helminth. Intisari Sains Medis, 2019;10(3):811-816.

20. Hardiyanti, L. T. dan Umniyati, S. R. Kualitas air, perilaku dan lingkungan pada infeksi parasit usus anak sekolah dasar di tepi sungai Batanghari. Berita Kedokteran Masyarakat, 2017;33.

21. Sari, Rita Kartika, Ratnawati, dan Livana PH. Gambaran faktor-faktor yang berpengaruh terhadap cakupan kepemilikan jamban sehat. Jurnal Ilmiah Permas: Jurnal Ilmiah STIKES Kendal, 2018;8(1):56-62.

22. Siddiq, M. Nuzul Azhim Ash. Penyakit infeksi dan pola makan dengan kejadian status gizi kurang berdasarkan $\mathrm{BB} / \mathrm{U}$ pada balita usia 6-24 bulan di wilayah kerja puskesmas tanah sepenggal [Skripsi] Jambi : Universitas Adiwangsa, 2014. 